\title{
Determinant Factors On Multidrug Resistant Tuberculosis (MDR TB) Control At RSUD dr. Zainoel Abidin Banda Aceh In 2018
}

\author{
Nurlina*, Said Usman, Mudatsir, Nurjannah, Irwan Saputra \\ Medicine Faculty of Syiah Kuala University, Indonesia \\ *dr.nurlina3@gmail.com
}

\begin{abstract}
For the last few years, the TB issue is worse due the increasinge of Multidrug Resistant Tuberculosis (MDR TB) which resistant to rifampicin and isoniazid. Globally, the amount of MDR TB was 160,684 cases in 1997. The success rate of the MDR TB is strongly related to the service providers / health staff, patients and TB programs. This study aims to investigate the MDR TB determinant at the Regional Hospital of dr. Zainoel Abidin (RSUD dr. Zainoel Abidin) in Banda Aceh in 2018. This study used cross sectional approach using, primary and secondary data. The primary data ware obtained by using questionnaires about the system and the strategy of the services, role of task, and the therapy services of the MDR TB control. The secondary data were obtained from the MDR TB patients' medical records who strarted the treatment in 2018. There were 41 samples of MDR TB patients taken by using total sampling technique and analyzed with chi-square and followed by logistic regression. The results of the questionnaire on the management system on the MDR TB control is $70.7 \%$ which is good and from 41 samples of MDR TB patients, the related factors to the MDR TB control is comorbiditas ( $\mathrm{p}$ value $=0.032$ ) and the patients discipline in taking drug ( $\mathrm{p}$ value $=0.001$ ), where as the unrelated factors is age and sex. From the results of the logistic regression test, the most related factor on the MDR TB control at RSUD dr. Zainoel Abidin is the patients' discipline in taking medicine with $p$ value of 0.006 and an OR value 11.50. Conclusion: The management system on the MDR TB control at RSUD dr. Zainoel Abidin has been running well, but the implementation of the therapy depends on the patients' discipline in taking drugsugs.
\end{abstract}

Keywords : Determinant Factors, Management system, MDR TB control

Received August 2, 2020; Revised August 26, 2020; Accepted September 8, 2020 


\section{STRADA Jurnal Ilmiah Kesehatan}

DOI: $10.30994 /$ sjik.v9i2.377

ISSN: 2252-3847 (print); 2614-350X (online)

Vol.9 No.2 November 2020 Page.872-878

\section{BACKGROUND}

Tuberculosis is an important public health issue in the world and becomes the top 10 cause of death. Globally, there were 10 million cases of tuberculosis in 2018. Indonesia is in the third place after India and China (WHO, 2019). A further health problem in recent years is the increasing of Multidrug Resistant Tuberculosis (MDR TB) which is resistant to rifampicin and isoniazid. The main factors related to tuberculosis drug resistance in Indonesia are including: (1) implementation of DOTS in hospitals and health care facilities that are still of low quality, (2) Increasing of TB-HIV co-infection, (3) Weak surveillance systems and (4) Inadequate handling of drug-resistant TB cases (Kementrian Kesehatan RI, 2011).

MDR TB is influenced by several risk factors, including treatment history, indiscipline treatment, age, sex, side effects of anti tuberculosis drugs, no control during the treatment, knowledge on MDR TB, and DOTS Plus. The of MDR TB is more management complicated and requires more attention than TB without resistance (Widiastuti, Subronto, \& Promono, 2017).

The management system has an important role in MDR TB control, including at RSUD dr. Zainoel Abidin Banda Aceh which is the MDR TB referral hospital. This study aims to examine the determinant of MDR TB control at dr.Zainoel Abidin Regionalhospital Banda Aceh, in order to improve the quality of services and the TB programs management at the hospital.

\section{METHODS}

This study used a cross sectional approach. The study was conducted from May to June 2020. The independent variables in this study were age, sex, comorbidity, and patients' compliance in taking drugs, while the dependent variable was MDR TB control with controlled measurement results when the patient finished treatment, and was declared cured by a pulmonary specialist doctor, based on the results of the examination and the results of BTA. It is uncontrolled if the patients finished the treatment, but endsed with complete treatment, dies, fails, defaulted.

Respondents in this study were 41 health staff in the Integrated Tuberculosis Service Installation, who were willing to participate in the study. There were 41 samples of MDR TB patients' who finished undergoing treatment at the hospital in 2018. Structured questionnaires were used to examine the service system and patient medical records were used to examine the patient's age, sex, comorbidity, and patients' compliance as well as final outcome of treatment.

Data was analyzed descriptively to determine the percentage of each variable. Bivariate analysis was conducted to determine whether there was a correlation between age, sex, comorbidity and patients' compliance with MDR TB control, using the Chi -Square test. Further, multivariate analysis was carried out using, logistic regression test to determine the most dominant factor in controlling MDR TB. This research was conducted after obtaining ethical approval from the Health Research Ethics Committee of the Medicine Faculty, Syiah Kuala University / Dr. Zainoel Abidin hospital.

\section{RESULTS}

The results of the study obtained from 41 respondents who have answered the management system questionnaire on MDR TB control can be seen in table 1 . 


\section{STRADA Jurnal Ilmiah Kesehatan}

DOI: $10.30994 /$ sjik.v9i2.377

ISSN: 2252-3847 (print); 2614-350X (online)

Vol.9 No.2 November 2020 Page.872-878

Table 1. Results of Univariate Management Systems on MDR TB Control

\begin{tabular}{lcc}
\hline \multicolumn{1}{c}{ Variable } & Frequency & Percentage \\
\hline Manajement system & & \\
$-\quad$ Good & 29 & 70.7 \\
$-\quad$ Not so good & 12 & 29.3 \\
\hline \multicolumn{1}{c}{ Total } & 41 & 100.0 \\
\hline
\end{tabular}

Table 1 shows the results of management system on MDR TB control is good $70.7 \%$ and not so good is $29.3 \%$.

Table 2. Characteristics of MDR TB Patients

\begin{tabular}{lcc}
\hline \multicolumn{1}{c}{ Variable } & Frequency & Percentage \\
\hline Age & 29 & 70.7 \\
$-\quad<50$ years old & 12 & 29.3 \\
$-\quad \geq 50$ years old & & \\
Sex & 34 & 82,9 \\
$-\quad$ Male & 7 & 17,1 \\
$-\quad$ Female & 19 & 46,3 \\
Comorbidity & 22 & 53,7 \\
$-\quad$ Yes & 21 & 51.2 \\
$-\quad$ No & 20 & 48.8 \\
Pasient Compliance intaking drug & 41 & 100,0 \\
$-\quad$ No & Yes & \\
\hline
\end{tabular}

Table 2, shows the results of MDR TB patients characteristics at RSUDZA 2018 based on age less than 50 years $(70.7 \%)$ and more than 50 years $(29.3 \%)$, male $(82.9 \%)$ and female. $(17.1 \%)$, there are comorbidities $(46.3 \%)$ and no comorbidities (53.7\%), patients are discipline in taking drugs $(48.8 \%)$ and indiscipline patients $(51.2 \%)$.

Table 3. The Correlation Characteristics between Patient's and MDR TB Control

\begin{tabular}{|c|c|c|c|c|c|}
\hline \multirow[t]{2}{*}{ Characteristics } & \multicolumn{2}{|c|}{ MDR TB Control } & \multirow[t]{2}{*}{ Total (\%) } & \multirow[t]{2}{*}{$P$ value } & \multirow{2}{*}{$\begin{array}{c}\text { OR } \\
(95 \% \mathrm{CI})\end{array}$} \\
\hline & Uncontrolled & $\begin{array}{c}\text { Under } \\
\text { Controlled }\end{array}$ & & & \\
\hline \multicolumn{6}{|l|}{$\overline{\text { Age }}$} \\
\hline$<55$ years & $\begin{array}{c}16 \\
(55.2 \%)\end{array}$ & $\begin{array}{c}13 \\
(44.8 \%)\end{array}$ & $\begin{array}{c}29 \\
(100 \%)\end{array}$ & 0.729 & $0.61(0.15-2.51)$ \\
\hline$\geq 55$ years & $\begin{array}{c}8 \\
(66.7 \%)\end{array}$ & $\begin{array}{c}4 \\
(33.3 \%)\end{array}$ & $\begin{array}{c}12 \\
(100 \%)\end{array}$ & & \\
\hline \multicolumn{6}{|l|}{ Sex } \\
\hline Male & $\begin{array}{c}18 \\
(52.9 \%)\end{array}$ & $\begin{array}{c}16 \\
(47.1 \%)\end{array}$ & $\begin{array}{c}34 \\
(100 \%)\end{array}$ & 0.207 & $0.18(0.02-1.72)$ \\
\hline Female & $\begin{array}{c}6 \\
(85.7 \%)\end{array}$ & $\begin{array}{c}1 \\
(14.3 \%)\end{array}$ & $\begin{array}{c}7 \\
(100 \%)\end{array}$ & & \\
\hline \multicolumn{6}{|l|}{ Comorbidity } \\
\hline Yes & $\begin{array}{c}15 \\
(78.9 \%)\end{array}$ & $\begin{array}{c}4 \\
(21.1 \%)\end{array}$ & $\begin{array}{c}19 \\
(100 \%)\end{array}$ & 0.032 & $5.41(1.34-21.79)$ \\
\hline No & $\begin{array}{c}9 \\
(40.9 \%)\end{array}$ & $\begin{array}{c}13 \\
(59.1 \%)\end{array}$ & $\begin{array}{c}22 \\
(100 \%)\end{array}$ & & \\
\hline \multicolumn{6}{|l|}{$\begin{array}{l}\text { Patients } \\
\text { compliance } \\
\text { intaking drug }\end{array}$} \\
\hline No & $\begin{array}{c}18 \\
(85.7 \%)\end{array}$ & $\begin{array}{c}3 \\
(14.3 \%)\end{array}$ & $\begin{array}{c}21 \\
(100 \%)\end{array}$ & 0.001 & $14.0(2.96-66.08)$ \\
\hline
\end{tabular}




\section{STRADA Jurnal Ilmiah Kesehatan}

DOI: $10.30994 /$ sjik.v9i2.377

ISSN: 2252-3847 (print); 2614-350X (online)

Vol.9 No.2 November 2020 Page.872-878

\begin{tabular}{cccc}
\hline Yes & 6 & 14 & 20 \\
& $(30.0 \%)$ & $(70.0 \%)$ & $(100 \%)$ \\
\hline Total (\%) & 24 & 17 & 41 \\
& $(58.8 \%)$ & $(41.5 \%)$ & $(100 \%)$
\end{tabular}

Table 3. Shows the results of patients who were less than 55 years $(44.8 \%)$ under control and $(55.2 \%)$ uncontrolled. From the bivariate statistical results, the p value of 0.729 means that there is no correlation between patient age and MDR TB control. Shows the results of all the male patients $(52.9 \%)$ are uncontrolled and female $(47.1 \%)$ are under control. From the statistical test results, the p value of 0.207 means there is no correlation between sex with MDR TB control.

Shows that the patients with comorbid patients (78.9\%) are uncontrolled and under control $(21.1 \%)$. Statistical test results obtained $\mathrm{p}$ value 0.032 , meaning that there is a correlation between comorbidity with MDR TB control with an OR value of 5.41. Shows the results of patient's who are in dicipline in taking drug uncontrolled $(85.7 \%)$ and controlled $(14.3 \%)$, statistical test results obtained $\mathrm{p}$ value 0.001 , meaning that there is a correlation between discipline in taking drugs with the MDR TB control and the OR value is 14.0.

Table 4. The Results of Logistic Regression Analysis Test Model 1 on MDR TB Control

\begin{tabular}{cccc}
\hline Variable & P Value & OR & $95 \%$ CI \\
\hline Sex & 0,103 & 0,97 & $0,06-1,59$ \\
Comorbidity & 0,065 & 5,73 & $0,89-36,66$ \\
Patients compliance & 0,040 & 6,88 & $1,09-43,41$ \\
intaking drug & & &
\end{tabular}

Table 4 shows the results of logistic regression analysis model 1, the included variables were sex, comorbidity and patients compliance intaking drug. The selected variables has a significance value of $p$ value $<0.25$. Shows the final results of multivariate analysis, it was found that had a significant relationship with MDR TB control was the variable patients compliance intaking drug. The final results model logistic regression can be seen in the following table 5 .

Table 5. The Results of Logictic Regression Analysis Test Model 2 on MDR TB Control

\begin{tabular}{cccc}
\hline Variable & P Value & OR & $95 \%$ CI \\
\hline $\begin{array}{c}\text { Patients' compliance } \\
\text { intaking drug }\end{array}$ & 0.006 & 11.50 & $2.04-64.80$ \\
\hline
\end{tabular}

Table 5 shows the results of the most dominant factors related to MDR TB control is the patient's compliance intaking drug. The result of logistic regression statistical test obtained $\mathrm{p}$ value 0.006 and OR 11.50 , meaning that the patients who are compliance in taking drug have 11.5 times the chance of being controled for MDR TB.

\section{DISCUSSION}

The results indicated that the service management system, the role of officers, strategies and therapy services on the MDR TB control, awere good (70.7\%), meaning that the system management for MDR TB control in RSUD dr. Zainoel Abidin Banda Aceh has been running well. The result is in line with Wahyudi's study (2010) that the role of the officers have a positive effect on the success of TB control programs in general. (Kes et al., 2019). The implimentation of DOTS strategy at dr. Zainoel Abidin hospital has been running well. On the MDR TB management, that has been implemented is DOTS Plus strategy. The service system is a compleate, integraeted and qualified health efforts 


\section{STRADA Jurnal Ilmiah Kesehatan}

DOI: $10.30994 /$ sjik.v9i2.377

ISSN: 2252-3847 (print); 2614-350X (online)

Vol.9 No.2 November 2020 Page.872-878

including inprovement, preventive, treatment and rehabilitation in order to get better health status. (Kementrian Kesehatan RI, 2011)

Patients characteristics at dr. Zainoel Abidin hospital in 2018 can be seen in table 2. Based on the age, most of MDR TB patient are at productive age (less than 55 years old) as many as $70.7 \%$. Based on the previous studies, the most age were at the productive age(Sinaga, 2013), another study also mentioned that the majority age range was 15-54 years old (Aini \& Rufia, 2019). Based on the sex, male are more than $82.9 \%$ compared to female patients $(17.1 \%)$. This is due to the differences in exposure to the infection risk (including lifestyle such as smoking, and pollutant working area). The results were also consistent with the study of Liu et al. who stated that MDR TB patients are more men (He, Tao, Liu, Zhang, \& Li, 2017). Based on comorbidity, were are $53.7 \%$ with no comorbidity and the rest are $46.3 \%$. Based on the compliance, there weare $51.2 \%$ patients who were not compliance $48.8 \%$ were compliance. Based on the MDR TB control there are $41.5 \%$ under control and $58.5 \%$ uncontrolled.

The results showed no correlation between patient age and MDR TB control. However, the study conducted by Agustina et al (2017) showed a correlation between age and treatment outcomes. Other studies have also shown that age $<44$ years is a protective factor from poor treatment (Agustina, Maulida, \& Yovsyah, 2018). In a study conducted by Stosic et al (2018) indicated, that those who were less than 30 years of age have 7 times higher to the MDR TB risk than those who were more than 30 years old (Stosic et al., 2018).

The results of this study shows, no correlation between sex of patients with MDR TB control. This is in line with the study conducted by Stosic et al. (2018), who said that there is no correlation between male and female as MDR TB risk factor.(Stosic et al., 2018). Base on study of Widiastuti et al (2017) also said that there is no correlation between sex and MDR TB cases. (Widiastuti et al., 2017). However, there are differences with the previous studies that show a significant correlation between sex and treatment outcomes. Differences in the study results may occur due to differences in the number of samples used, research locations and sample characteristics.

One of the comorbid diseases is Diabete Millitus (DM), if the DM patients are also infected by MDR TB, so MDR TB control is difficult to be done because of the sugar levels. In this study, the statistical test results of chi-square analysis obtained p-value 0.032 $<0.5$ and OR value 18.214. It means that there is a significant correlation between comorbidity and MDR TB control. And people with comorbidities have more risk 18.214 times so that difficult to be controlled. This study is in line with research conducted by Alfiyani et al, 2017, who said that MDR TB is related to comorbidity and discipline treatment (Alfiyani et al, 2017).

The results of discipline intaking drugs with the MDR TB control shows the p-value are 0.001. that the alternative hypothesis (Ha) is accepted, which meant that there was a significant correlation between treatment discipline and MDR TB control. and an OR value of 14.0 means that people who do not discipline to MDR TB treatment have a 14 times more risk for uncontrolled / than those who are discipline.

The results of this study is similiat with the results of Dwi Sarwani SR et al., (2012) study shows that there is a relationship between discipline of taking drugs with the MDR TB control, where as the patients who are not discipline intaking drugs have more riks 2.3 times suffering MDR TB compared to those who are discipline (Dwi Sarwani SR, Sri Nurlaela, 2012). It is also in line with the study conducted by I Made (2016) who said that 


\section{STRADA Jurnal Ilmiah Kesehatan}

DOI: $10.30994 /$ sjik.v9i2.377

ISSN: 2252-3847 (print); 2614-350X (online)

Vol.9 No.2 November 2020 Page.872-878

in discipline patients in MDR TB treatment have more risk 1.593 times compared to the discipline patients.

From the results of the multivariate statistical test analysis, the most significant MDR TB control analysis is discipline intaking drugs with a $p$ value 0.006 and OR value is 11.50 meaning that, patients who are not discipline intaking drugs have 11.50 times chance of not being cured or uncontrolled.

In line with the research conducted by Aris widiyanto (2016) who said there was a relationship between discipline intaking drugs and the recovery of the patients with BTA positive. It shows that if TB patients take discipline intaking drugs, the cure rate for TB patients will also increase. It is influenced by the willingness and motivation of the patients to recover, and the understanding of the desease that they follow the recommendation of taking drugs made by the medical staff. For indiscipline patients due to they are not compliance to long term medications treatment and lack of knowledge about the effects if they do not take drugs. In addition, the other desease history make patients feel confused because they have to take many kinds of drugs at the same time that cause potential indiscipline in doing treatment (Widiyanto, 2017).

There are many factors cause the patients indiscipline intaking drugs. Based on Dewi Hapsari Wulandari's study (2015), sad that the most dominant factor related to Tb patiens discipline in taking

drugs is the side effects of the drugs. TB patients with low drugs-side-effects are more discipline than the patients with high. Good knowlage of the disease and good attention form the medical staff also influence them discipline in performing medical threatment (Wulandari, 2015).

\section{CONCLUSION}

The management system for MDR TB control at RSUD dr. Zainoel Abidin was good, but the success of the management depends on the patient's compliance intaking drugs.

From the results of the study that directly related to MDR TB control at RSUD dr. Zainoel Abidin Banda Aceh is comorbidity and the patients discipline intaking drugs. Meanwhile, the patient's age and sex have no correlation with the MDR TB control. The most dominant factor statistically is patients discipline in taking drugs.

The author suggesteds a good coordination between health officer with patients, availability of online information media system, and application of treatment schedules to improve patients' compliance.

\section{REFERENCE}

Agustina, R., Maulida, R., \& Yovsyah. (2018). Faktor-Faktor yang Berhubungan dengan Kesuksesan Kesembuhan dari Pengobatan Regimen Pendek ( Short Treatment Regiment ) pada Pasien Tuberkulosis Resistensi Obat di Indonesia Tahun 2017 Factors Associated with Recovery Success after Short Treatment Regimen. Jurnal Epidemiologi Kesehatan Indonesia, 2(2), 65-71.

Aini, Z. M., \& Rufia, N. M. (2019). Karakteristik Penderita Tuberculosis Multidrug Resistant (TB MDR) di Sulawesi Tenggara Tahun 2014-2017. Medula, 6(2), 547557. https://doi.org/10.46496/medula.v6i2.6727

Alfiyani et al. (2017). Biopsychosocial Determinants of Multi Drug Resistant Tuberculosis in Surakarta. Journal of Epidemiology and Public Health, 66. https://doi.org/10.26911/mid.icph.2018.01.03

Dwi Sarwani SR, Sri Nurlaela, I. Z. A. (2012). Analisis Faktor Resiko Multidrug Resistant 


\section{STRADA Jurnal Ilmiah Kesehatan}

DOI: $10.30994 /$ sjik.v9i2.377

ISSN: 2252-3847 (print); 2614-350X (online)

Vol.9 No.2 November 2020 Page.872-878

Tuberculosis (MDR-TB) (Studi Kasus Di BP4 Purwokerto). Jurnal Kesehatan Masyarakat, 8(1), 62-68.

He, X. chun, Tao, N. ning, Liu, Y., Zhang, X. xin, \& Li, H. chen. (2017). Epidemiological trends and outcomes of extensively drug-resistant tuberculosis in Shandong, China. BMC Infectious Diseases, 17(1), 1-9. https://doi.org/10.1186/s12879-017-2652-x

Kementrian Kesehatan RI. (2011). Rencana Aksi Nasional Programmatic Management of Drug resistance Tuberculosis Pengendalian Tuberkulosis Indonesia: 2011-2014. Kementerian Kesehatan Republik Indonesia, 6-18.

Kes, M., Hardhana, B., Siswanti, T., Sibuea, F., Widiantini, W., Susanti, M. I., ... Maula, R. (2019). Profil Kesehatan Indonesia Tahun 2019.

Sinaga, B. Y. M. (2013). Karakteristik Penderita Multidrug Resistant Tuberculosis yang Mengikuti Programmatic Management of Drug-Resistant Tuberculosis di Rumah Sakit Umum Pusat H. Adam Malik Medan. Journal Respirologi Indonesia, 33(4), 221-229. Retrieved from http://repository.usu.ac.id/bitstream/handle/123456789/69962/Fulltext.pdf?sequence= $1 \&$ isAllowed $=\mathrm{y}$

Stosic, M., Vukovic, D., Babic, D., Antonijevic, G., Foley, K. L., Vujcic, I., \& Grujicic, S. S. (2018). Risk factors for multidrug-resistant tuberculosis among tuberculosis patients in Serbia: A case-control study. BMC Public Health, 18(1), 91-96. https://doi.org/10.1186/s12889-018-6021-5

WHO. (2019). WHO guidelines on tuberculosis infection prevention and control, 2019 update.

Widiastuti, E. N., Subronto, Y. W., \& Promono, D. (2017). Determinan Kejadian MultiDrug Resistant Tuverculosis di Rumah Sakit Dr. Sardjito Yogyakarta. Berita Kedokteran Masyarakat, 33(7), 325-330. Retrieved from https://jurnal.ugm.ac.id/bkm/article/view/18290/20525

Widiyanto, A. (2017). Hubungan Kepatuhan Minum Obat Dengan Kesembuhan Pasien Tuberkulosis Paru BTA Positif Di Puskesmas Delanggu Kabupaten Klaten. Interest : Jurnal Ilmu Kesehatan, 6(1), 7-12. https://doi.org/10.37341/interest.v6i1.71

Wulandari, D. (2015). Analisis Faktor-Faktor yang Berhubungan dengan Kepatuhan Pasien Tuberkulosis Paru Tahap Lanjutan Untuk Minum Obat di RS Rumah Sehat Terpadu Tahun 2015. Jurnal Administrasi Rumah Sakit, 2(1), 17-28. 